\title{
MXI1 wt Allele
}

National Cancer Institute

\section{Source}

National Cancer Institute. MXI1 wt Allele. NCI Thesaurus. Code C52228.

Human MXI1 wild-type allele is located within 10q24-q25 and is approximately $80 \mathrm{~kb}$ in length. This allele, which encodes MAX-interacting protein 1, is involved in transcriptional suppression. 